\title{
Breast Implant-Associated Anaplastic Large Cell Lymphoma Following Gender Reassignment Surgery: A Review of Presentation, Management, and Outcomes in the Transgender Patient Population
}

\author{
Shruti Zaveri ${ }^{1}$ (D), Alice Yao ${ }^{2}$ (D), Hank Schmidt ${ }^{3}$ (D) \\ ${ }^{1}$ Department of Surgery, The Mount Sinai Hospital, New York, NY, USA \\ ${ }^{2}$ Division of Plastic and Reconstructive Surgery, Department of Surgery, The Mount Sinai Hospital, New York, NY, USA \\ ${ }^{3}$ Dubin Breast Center, Tisch Cancer Institute, The Mount Sinai Hospital, New York, NY, USA
}

\begin{abstract}
Breast implant-associated anaplastic large cell lymphoma (BIA-ALCL) is a rare peripheral T-cell lymphoma with approximately 650-700 reported cases worldwide. The incidence, however, is increasing as more practitioners become aware of the diagnosis, and recent studies show that early diagnosis and treatment is critical to improve prognosis. There have been four cases of BIA-ALCL in total reported in the transgender population in the literature. These reported cases were reviewed in detail to determine presentation and management of BIA-ALCL in transgender patients compared to the larger population of BIA-ALCL patients. This review highlights BIA-ALCL in transgender women, a population that is often excluded from breast screening and follow-up. Transgender women may not routinely go through the same post-operative follow-up protocols as patients with breast implants for breast cancer reconstruction and can thus be at risk for delayed recognition and diagnosis. BIA-ALCL is a rare complication of breast implantation, and it is important to counsel all patients undergoing implant placement, including transgender women, on its risk.

Keywords: BIA-ALCL, implant, lymphoma, transgender
\end{abstract}

Cite this article as: Zaveri S, Yao A, Schmidt H. Breast Implant-Associated Anaplastic Large Cell Lymphoma Following Gender Reassignment Surgery: A Review of Presentation, Management, and Outcomes in the Transgender Patient Population. Eur J Breast Health 2020; 16(3): 162-166.

\section{Introduction}

Breast implant-associated anaplastic large cell lymphoma (BIA-ALCL) is a rare peripheral T-cell lymphoma discovered in recent years as a potential complication associated with breast implants. It was first described in 1997 (1), and has since been reported in approximately 650-700 cases worldwide (2). Only a fraction of these cases have been published in the literature (3). Some of these cases may be duplicates, thus the exact number of cases continues to be debated. While the precise incidence and prevalence is unknown, there is an estimated incidence of 2 per million per year and a lifetime prevalence of 33 per 1 million women with textured breast implants (4). Given the rarity of the disease, developing a protocol for diagnosis has been difficult and determining optimal treatment even more challenging. Recognition of BIA-ALCL is increasing as more practitioners become aware of the diagnosis, and it is important to identify the presentation of BIA-ALCL in all populations, including transgender women, that may be affected.

Gender-affirmation surgery is a critical component of the management of gender dysphoria. For male-to-female transgender women, breast implants are routinely used as a part of gender reassignment surgery (5). Transgender women typically initiate hormonal therapy for feminization of the chest, but response to hormonal therapy varies widely. Current evidence suggests that $60-70 \%$ of trans-women seek surgical breast augmentation in addition to cross-sex hormone therapy as a part of their feminization (6). The number of adolescents identified with gender dysphoria is increasing, and as such, the use of breast implants in this population is also on the rise (7). Given the increasing incidence of BIA-ALCL in all patients with breast implants, it is important to recognize BIA-ALCL in the transgender population. This review highlights the presentation, management, and outcomes of BIA-ALCL in transgender women, a population that is often excluded from breast screening and follow-up. 
Table 1. Presentation of BIA-ALCL in transgender patients

\begin{tabular}{|c|c|c|c|c|}
\hline & Patient 1 & Patient 2 & Patient 3 & Patient 4 \\
\hline Age at presentation (years) & 49 & 56 & 40 & 54 \\
\hline Age at implant placement (years) & 42 & 36 & 33 & 37 \\
\hline Interval from placement to initial symptoms (years) & 1 & 5 & 5 & 9 \\
\hline Interval from placement to presentation (years) & 7 & 20 & 7 & 17 \\
\hline Interval from initial symptoms to diagnosis (years) & 6 & 15 & 2 & 8 \\
\hline Type of implant & Textured & Textured & Textured & Textured \\
\hline Hormonal therapy & 1 year & 0 years & 6 years & 11 years \\
\hline Initial symptoms & $\begin{array}{l}\text { Pain } \\
\text { Discomfort } \\
\text { Pruritus }\end{array}$ & $\begin{array}{c}\text { Pain } \\
\text { Fevers } \\
\text { Capsular } \\
\text { contracture }\end{array}$ & $\begin{array}{c}\text { Pain } \\
\text { Discomfort }\end{array}$ & $\begin{array}{l}\text { Pain } \\
\text { Pruritus } \\
\text { Hyperpig- } \\
\text { mentation }\end{array}$ \\
\hline Presenting symptoms & $\begin{array}{c}\text { Cutaneous } \\
\text { papules, } \\
\text { seroma, palpable } \\
\text { mass }\end{array}$ & $\begin{array}{l}\text { Periprosthetic } \\
\text { seroma, } \\
\text { implant } \\
\text { rupture, } \\
\text { palpable mass }\end{array}$ & $\begin{array}{l}\text { Palpable } \\
\text { mass }\end{array}$ & $\begin{array}{l}\text { Multiple } \\
\text { palpable } \\
\text { masses }\end{array}$ \\
\hline
\end{tabular}

\section{Cases of BIA-ALCL in Transgender Patients}

There are four cases of BIA-ALCL in total in the transgender population reported in the literature (8-11). These reported cases were reviewed in detail to determine whether there are any discrepancies in the presentation and management of BIA-ALCL in transgender patients compared to the population at large.

In the reported transgender cases, the mean age at implant placement was 37 years and mean age at presentation was 49.75 years (Table 1). Mean time from implant placement to initial symptoms was 5 years while the mean time to presentation was over 12 years. Each of the reported cases in the transgender population involved the use of textured implants, and initial symptoms were vague, including breast pain, discomfort, and pruritis. By the time of presentation, each of the patients a palpable breast lesion.

The breast imaging of choice-ultrasound, mammogram, or MRIvaried between the cases, however each patient underwent Positron Emission-Tomography (PET) for evaluation of metastatic spread (Table 2). Each patient underwent implant removal with capsulectomy and mass excision, however the extent of the resection varied by case. The pectoral muscle was resected in half of the cases. Evaluation of lymph nodes also varied by case-the first reported case included an axillary node dissection and was found to have negative nodes. Subsequent cases either did not check axillary nodes or utilized a sentinel lymph node (SLN) biopsy. The case in which a SLN biopsy was employed identified 1 positive lymph node. This patient underwent adjuvant radiation therapy with a total of 36 grays (Gy) delivered in 18 fractions to right axilla and 30Gy to right breast. Three out of four patients were treated with adjuvant chemotherapy consisting of 4 to 6 cycles of cyclophosphamide, doxorubicin, vincristine, and prednisone (CHOP) therapy. All patients presented at a late stage with lymphoma infiltrates beyond the capsule, thus falling under the T4 tumor extent category of the American Joint Committee on Cancer TNM Staging of BIA-ALCL (Table 3).
Each of the patients was tumor-free at 6 months post-surgical excision; 2 years was the longest follow-up time in the reported cases.

\section{Discussion and Conclusion}

\section{Pathogenesis and presentation}

Anaplastic large cell lymphoma (ALCL) is a type of non-Hodgkin $\mathrm{T}$-cell lymphoma that is characterized by the presence of lymphoid cells that express cell-surface protein CD30. Approximately 60\% of non-implant-associated ALCL cases are anaplastic lymphoma kinase (ALK) positive; however, BIA-ALCL is found to be ALKnegative, thus differentiating systemic ALCL from BIA-ALCL. ALCL arises predominantly from the implant capsule, and the vast majority of reported cases have thus far occurred with the use of textured implants (12). While the exact pathogenesis of Breast Implant-Associated ALCL is still unknown, overexpression of CD30 is often seen in states of chronic inflammation, and it is proposed that BIA-ALCL develops from chronic inflammation in the breast secondary to the implant. Theories include bacterial biofilm growth on the implant surface and abnormal immune responses to textured implants (13-16). Several studies have highlighted that a chronic biofilm infection on implants can cause capsular contracture. An animal study compared biofilm formation in textured versus smooth implants and showed significantly higher numbers of lymphocytes, particularly T-cells, in bacterial biofilm on textured implants compared to smooth implants, furthering the evidence to support the theory that a chronic biofilm infection on textured implants leads to T-cell hyperplasia and may potentiate BIA-ALCL (16).

There are several differences in the typical presentation of BIA-ALCL compared to the presentation of the disease in the transgender patient population. A recently published large systematic review of 115 BIA-ALCL articles and 95 patients found that $66 \%$ of patients presented with a late-onset seroma, $8 \%$ of patients presented with a new breast mass, and others presented with capsular con- 
Table 2. Diagnosis and management of BIA-ALCL in transgender patients

\begin{tabular}{|c|c|c|c|c|}
\hline & Patient 1 & Patient 2 & Patient 3 & Patient 4 \\
\hline Imaging & $C T$, Breast MRI, PET & $\begin{array}{l}\text { Ultrasound, Mammogram, } \\
\text { PET }\end{array}$ & Breast MRI, PET & $\begin{array}{l}\text { Ultrasound, } \\
\text { Mammogram, PET }\end{array}$ \\
\hline Surgery & $\begin{array}{l}\text { Unilateral mastectomy } \\
\text { (implant previously removed) } \\
\text { with resection of pectoral } \\
\text { muscle, and axillary node } \\
\text { dissection }\end{array}$ & $\begin{array}{l}\text { Bilateral implant removal } \\
\text { with capsulectomy of } \\
\text { affected side }\end{array}$ & $\begin{array}{l}\text { Unilateral implant } \\
\text { removal with } \\
\text { capsulectomy, mass } \\
\text { resection with part } \\
\text { of pectoral muscle }\end{array}$ & $\begin{array}{l}\text { Bilateral implant } \\
\text { removal with } \\
\text { capsulectomy of } \\
\text { affected side and } \\
\text { sentinel lymph node } \\
\text { biopsy, excision of } \\
\text { active lymph node }\end{array}$ \\
\hline Implant status & Intact & $\begin{array}{l}\text { Intact (previous rupture } \\
\text { and exchange) }\end{array}$ & Ruptured & Intact \\
\hline Margin status & Positive & Negative & Negative & Positive \\
\hline Axillary status & Negative & Unchecked & Unchecked & Positive \\
\hline Radiation & No radiation therapy & No radiation therapy & No radiation therapy & $\begin{array}{l}\text { Total 36Gy in } 18 \\
\text { fractions to R axilla and } \\
30 \text { Gy to R breast }\end{array}$ \\
\hline Chemotherapy & 4 cycles of $\mathrm{CHOP}$ & No chemotherapy & 6 cycles of CHOP & 6 cycles of $\mathrm{CHOP}$ \\
\hline
\end{tabular}

tracture, skin findings, or axillary lymphadenopathy (3). While all the transgender patient cases reviewed noted the presence of vague implant-related symptoms such as pain or pruritus and a seroma in the years prior to presentation, they did not present for evaluation until the development of a palpable mass. The mean time to presentation in the overall BIA-ALCL population is 8-10 years after implant placement $(3,17,18)$ compared to 13 years in the transgender patients reviewed. Each of the transgender patients developed symptoms on average 5 years following implant placement, however all the patients did not present for evaluation until at least 2 years following initial symptoms.

\section{Diagnosis and treatment}

Recent guidelines recommend that all patients who present with a late-onset periprosthetic fluid collection should be evaluated for BIA-ALCL. Ultrasound can be used to identify the seroma and help determine the presence of masses surrounding the capsule (19). Seroma aspiration with seroma fluid cytology or ultrasound-guided core needle biopsy in cases presenting with a mass can be used to confirm the diagnosis. All reported cases of BIA-ALCL have been anaplastic lymphoma kinase (ALK)-negative and CD30-positive. Anaplastic large cell lymphomas are usually FDG avid; thus, once the diagnosis is confirmed, PET CT can be used to determine the extent of the disease (20-22).

The 2019 National Comprehensive Cancer Network (NCCN) guidelines outline both the traditional Ann Arbor staging system for non-Hodgkin lymphoma as well as a solid tumor staging system based on tumor, lymph node, and metastasis (TNM) status (23). The Ann Arbor staging system divides BIA-ALCL based on status of extranodal spread: stage IE (disease limited to a single extranodal site), stage IIE (extranodal disease with spread to local lymph nodes), or stage IV disease (spread to multiple extranodal sites). The tumor extent with invasion confined to or beyond the capsule. There are significant differences in the stage at diagnosis of BIA-ALCL in most patients compared to the reported transgender patients. 35$70 \%$ of typical BIA-ALCL cases are diagnosed at stage IA with tumor confined to the effusion or the luminal aspect of the capsule and no lymph node involvement (23). As seen in Table 3, all the transgender patients were diagnosed at a late stage, IIA and higher, with tumor infiltrates already spread beyond the capsule.

Given that our knowledge on the natural progression of the disease is still sparse, the optimal treatment protocol remains unclear. Complete surgical resection with removal of the implant, capsulectomy, and excision of any masses to clear margins has been shown to improve disease-free survival (23). The role for mastectomy and axillary staging with sentinel lymph node biopsy remains unclear. Per recent 2019 National Comprehensive Cancer Network (NCCN) guidelines in the United States, adjuvant radiation therapy is indicated for patients with local residual disease or unresectable disease with chest wall invasion, while adjuvant chemotherapy is indicated for patients with Stage II-IV disease (24).

The first case of BIA-ALCL in a transgender woman was reported in 2016, prior to these NCCN guidelines. This patient was found to have positive margins post-surgical resection but did not receive radiation therapy as would have been indicated per the new NCCN guidelines. In the last reported case, the patient received both chemotherapy and radiation following surgical resection given the finding of positive margins and multiple involved axillary lymph nodes. Excision of the contralateral implant may be considered given 2-4\% of patients develop bilateral disease (24). Reconstruction following surgical treatment of BIA-ALCL is still highly debated with recent guidelines suggesting reconstruction may be pursued after a 6 -month disease-free interval $(3,17,25)$. Despite the recent NCCN guidelines, we lack a precise treatment protocol for BIA-ALCL and 
Table 3. Outcomes of BIA-ALCL in transgender patients

\begin{tabular}{|c|c|c|c|c|}
\hline & Patient 1 & Patient 2 & Patient 3 & Patient 4 \\
\hline Year of report & 2015 & 2017 & 2018 & 2019 \\
\hline Ann-Arbor stage & Stage IE & Stage IE & Stage IE & Stage IIE \\
\hline TNM stage & T4N0M0 (Stage IIA) & T4N0M0 (Stage IIA) & T4N0MO (Stage IIA) & T4N2M0 (Stage III) \\
\hline Follow-up (years) & Tumor-free at 6 months & Tumor-free at 10 months & $\begin{array}{l}\text { Tumor-free at 2-year } \\
\text { follow-up }\end{array}$ & $\begin{array}{l}\text { Tumor-free at 1-year } \\
\text { follow-up }\end{array}$ \\
\hline Follow-up imaging & $\begin{array}{l}\text { Post-treatment PET with } \\
\text { no evidence of disease }\end{array}$ & Unknown & $\begin{array}{l}\text { Post-treatment PET } \\
\text { with no evidence of } \\
\text { disease }\end{array}$ & $\begin{array}{l}\text { Post-treatment PET with no } \\
\text { evidence of disease }\end{array}$ \\
\hline
\end{tabular}

there is still limited evidence on the extent of breast and axillary surgery needed for effective locoregional control.

Of note, transgender patients often receive antiandrogen therapy and supplementation with exogenous estrogens for breast development in the months prior to breast augmentation (26). The World Professional Association for Transgender Health recommends estrogen supplementation for at least one year after considering breast augmentation (5). It is unknown whether antiandrogen therapy may have an impact on neoplastic potential in the breast and risk of ALCL associated with implants (27).

\section{Outcomes and impact on clinical practice}

Breast implants are accepted as standard of care for cosmetic breast augmentation, reconstruction following mastectomy, and as in the patients discussed above, gender reassignment surgery (28). Implants remain the most common method for breast augmentation and reconstruction with currently more than an estimated 10 million women with implants worldwide (29). Textured implants were introduced in the 1980 s to combat capsular contracture, and since then, have been increasingly used for breast reconstruction in certain parts of the world, possibly leading to an increased risk of BIAALCL following implant placement. Textured implants previously represented approximately $10 \%$ of all breast implants and were recalled by one of their major manufacturers in 2019. Though a few other companies continue to produce textured implants legally, their use is now declining as patients and surgeons become more aware of BIA-ALCL and choose either smooth implants or autologous options instead.

Recent studies have shown that early diagnosis and surgical resection is critical to improved prognosis of BIA-ALCL $(23,24)$. For this reason, it is crucial that practitioners in plastic surgery, breast surgery, and primary care gain awareness of the disease and appropriate diagnosis and treatment pathways. Most of the discussion around BIA-ALCL has been in the plastic surgery literature (4, $17,30,31$ ), and there is need for increased awareness of this entity amongst not only surgeons but also primary care providers who may often be the first to encounter these patients. Furthermore, unlike breast cancer patients who have routine follow-up and screening, patients who have breast implants secondary to either cosmetic breast augmentation or as a part of gender reassignment surgery sometimes do not routinely follow-up with their plastic surgeons, thus carrying a risk of delayed diagnosis. Although there is a very small number of reported cases of BIA-ALCL in transgender patients, comparison of these cases to other patients with BIA-ALCL does highlight significant delay in presentation and diagnosis for this subset of patients.

This review highlights the presentation of BIA-ALCL in a transgender woman after breast implant placement as a part of gender reassignment surgery. The transgender patients reviewed had a longer mean time to presentation than typically cited in BIA-ALCL series, and each of the transgender patients was not diagnosed until at least 2 years following initial symptoms. The transgender patients were thus diagnosed a significantly advanced stages compared to most BIA-ALCL patients. Transgender women may not routinely go through the same post-operative follow-up protocols as patients with breast implants secondary to breast cancer reconstruction and can thus be at risk for delayed recognition and diagnosis. BIA-AL$\mathrm{CL}$ is a rare but serious complication of breast implantation and it is important to counsel all patients undergoing implant placement, including transgender women, on its risk.

Peer-review: Externally peer-reviewed.

Author Contributions: Concept - S.Z., H.S.; Design - S.Z., H.S.; Supervision - H.S., A.Y.; Data Collection and/or Processing - S.Z., A.Y.; Analysis and/or Interpretation - S.Z., H.S., A.Y.; Literature Search - S.Z., H.S., A.Y.; Writing Manuscript - S.Z., H.S., A.Y.; Critical Review - S.Z., H.S., A.Y.

Conflict of Interest: The authors have no conflicts of interest to declare.

Financial Disclosure: The authors declared that this study has received no financial support.

\section{References}

1. Keech JA, Jr., Creech BJ. Anaplastic T-cell lymphoma in proximity to a saline-filled breast implant. Plast Reconstr Surg 1997; 100: 554-555. (PMID: 9252643) [Crossref]

2. Maisel W. Breast Implant Associated-Anaplastic Large Cell Lymphoma (BIA-ALCL) - Letter to Health Care Providers: U.S. Food and Drug Administration 2019 [Web Document]. Available from: https://www.fda. gov/medical-devices/letters-health-care-providers/breast-implant-associated-anaplastic-large-cell-lymphoma-bia-alcl-letter-health-care-providers.

3. Leberfinger AN, Behar BJ, Williams NC, Rakszawski KL, Potochny JD, Mackay DR, Ravnic DJ. Breast Implant-Associated Anaplastic Large Cell Lymphoma: A Systematic Review. JAMA Surg 2017; 152: 1161-1168. (PMID: 29049466) [Crossref] 
4. Doren EL, Miranda RN, Selber JC, Garvey PB, Liu J, Medeiros LJ, et al. U.S. Epidemiology of Breast Implant-Associated Anaplastic Large Cell Lymphoma. Plast Reconstr Surg 2017; 139: 1042-1050. (PMID: 28157769) [Crossref]

5. Eli Coleman WB, Marsha Botzer. Standards of Care for the Health of Transsexual, Transgender, and Gender-Nonconforming People. 7 ed: World Professional Association for Transgender Health (WPATH); 2012.

6. Wierckx K, Gooren L, T'Sjoen G. Clinical review: Breast development in trans women receiving cross-sex hormones. J Sex Med 2014; 11: 12401247. (PMID: 24618412) [Crossref]

7. Aitken M, Steensma TD, Blanchard R, VanderLaan DP, Wood H, Fuentes A, Spegg C, Wasserman L, Ames M, Fitzsimmons CL, Leef JH, Lishak V, Reim E, Takagi A, Vinik J, Wreford J, Cohen-Kettenis PT, de Vries ALC, Kreukels BPC, Zucker KJ. Evidence for an altered sex ratio in clinic-referred adolescents with gender dysphoria. J Sex Med 2015; 12: 756-763. (PMID: 25612159) [Crossref]

8. Orofino N, Guidotti F, Cattaneo D, Sciume M, Gianelli U, Cortelezzi A, Iurlo A. Marked eosinophilia as initial presentation of breast implantassociated anaplastic large cell lymphoma. Leuk Lymphoma 2016; 57: 2712-2715. (PMID: 26984254) [Crossref]

9. de Boer M, van der Sluis WB, de Boer JP, Overbeek LIH, van Leeuwen FE, Rakhorst HA, van der Hulst RRWJ, Hijmering NJ, Bouman MB, de Jong D. Breast Implant-Associated Anaplastic Large-Cell Lymphoma in a Transgender Woman. Aesthet Surg J 2017; 37: NP83-NP7. (PMID: 29036941) [Crossref]

10. Patzelt M, Zarubova L, Klener P, Barta J, Benkova K, Brandejsova A, Trneny M, Gürlich R, Sukop A. Anaplastic Large-Cell Lymphoma Associated with Breast Implants: A Case Report of a Transgender Female. Aesthetic Plast Surg 2018; 42: 451-455. (PMID: 29101436) [Crossref]

11. Ali N, Sindhu K, Bakst RL. A Rare Case of a Transgender Female With Breast Implant-Associated Anaplastic Large Cell Lymphoma Treated With Radiotherapy and a Review of the Literature. J Investig Med High Impact Case Rep 2019; 7: 2324709619842192. (PMID: 31010324) [Crossref]

12. BIA-ALCL Physician Resources: American Society of Plastic Surgeons; 2019 [Web Document]. Available from: https://www.plasticsurgery.org/ for-medical-professionals/health-policy/bia-alcl-physician-resources.

13. Story SK, Schowalter MK, Geskin LJ. Breast implant-associated ALCL: a unique entity in the spectrum of CD30+ lymphoproliferative disorders. Oncologist 2013; 18: 301-307. (PMID: 23429741) [Crossref]

14. Blombery P, Thompson ER, Jones K, Arnau GM, Lade S, Markham JF, Li J, Deva A, Johnstone RW, Khot A, Prince HM, Westerman D. Whole exome sequencing reveals activating JAK1 and STAT3 mutations in breast implant-associated anaplastic large cell lymphoma anaplastic large cell lymphoma. Haematologica 2016; 101: e387-90. (PMID: 27198716) [Crossref]

15. Kadin ME, Morgan J, Xu H, Epstein AL, Sieber D, Hubbard BA, Adams Jr WP, Bacchi CE, Goes JCS, Clemens MW, Medeiros LJ, Miranda RN. IL-13 is produced by tumor cells in breast implant-associated anaplastic large cell lymphoma: implications for pathogenesis. Hum Pathol 2018; 78: 54-62. (PMID: 29689246) [Crossref]

16. Hu H, Jacombs A, Vickery K, Merten SL, Pennington DG, Deva AK. Chronic biofilm infection in breast implants is associated with an increased T-cell lymphocytic infiltrate: implications for breast implantassociated lymphoma. Plast Reconstr Surg 2015; 135: 319-329. (PMID: 25383716) [Crossref]

17. Shine JJ, Boghossian E, Beauchemin G, Papanastasiou VW, Borsuk DE. Breast Implant-Associated Anaplastic Large Cell Lymphoma: Immediate or Delayed Implant Replacement? Aesthetic Plast Surg 2018; 42: 14921498. (PMID: 30094550) [Crossref]
18. Clemens MW, Brody GS, Mahabir RC, Miranda RN. How to Diagnose and Treat Breast Implant-Associated Anaplastic Large Cell Lymphoma. Plast Reconstr Surg 2018; 141: 586e-599e. (PMID: 29595739) [Crossref]

19. O'Neill AC, Zhong T, Hofer SOP. Implications of Breast Implant-Associated Anaplastic Large Cell Lymphoma (BIA-ALCL) for Breast Cancer Reconstruction: An Update for Surgical Oncologists. Ann Surg Oncol 2017; 24: 3174-3179. (PMID: 28762113) [Crossref]

20. Kim B, Predmore ZS, Mattke S, van Busum K, Gidengil CA. Breast Implant-associated Anaplastic Large Cell Lymphoma: Updated Results from a Structured Expert Consultation Process. Plast Reconstr Surg Glob Open 2015; 3: e296. (PMID: 25674377) [Crossref]

21. Adrada BE, Miranda RN, Rauch GM, Arribas E, Kanagal-Shamanna R, Clemens MW, Fanale M, Haideri N, Mustafa E, Larrinaga J, Reisman NR, Jaso J, You MJ, Young KH, Medeiros LJ, Yang W. Breast implantassociated anaplastic large cell lymphoma: sensitivity, specificity, and findings of imaging studies in 44 patients. Breast Cancer Res Treat 2014; 147: 1-14. (PMID: 25073777) [Crossref]

22. Cahu X, Bodet-Milin C, Brissot E, Maisonneuve H, Houot R, Morineau N, Solal-Celigny P, Godmer P, Gastinne T, Moreau P, Moreau A, Lamy T, Kraber-Bodere F, Le Gouill S. 18F-fluorodeoxyglucose-positron emission tomography before, during and after treatment in mature T/NK lymphomas: a study from the GOELAMS group. Ann Oncol 2011; 22: 705-711. (PMID: 20739714) [Crossref]

23. Clemens MW, Medeiros LJ, Butler CE, Hunt KK, Fanale MA, Horwitz S, Weisenburger DD, Liu J, Morgan EA, Kanagal-Shamanna R, Parkash V, Ning J, Sohani AR, Ferry JA, Mehta-Shah N, Dogan A, Liu H, Thormann N, Di Napoli A, Lade S, Piccolini J, Reyes R, Williams T, McCarthy CM, Hanson SE, Nastoupil LJ, Gaur R, Oki Y, Young KH, Miranda RN. Complete Surgical Excision Is Essential for the Management of Patients With Breast Implant-Associated Anaplastic Large-Cell Lymphoma. J Clin Oncol 2016; 34: 160-168. (PMID: 26628470) [Crossref]

24. Clemens MW, Jacobsen ED, Horwitz SM. 2019 NCCN Consensus Guidelines on the Diagnosis and Treatment of Breast Implant-Associated Anaplastic Large Cell Lymphoma (BIA-ALCL). Aesthet Surg J 2019; 39(Supplement 1): S3-S13. (PMID: 30715173) [Crossref]

25. Lamaris GA, Butler CE, Deva AK, Miranda RN, Hunt KK, Connell T, Lipa JE, Clemens MW. Breast Reconstruction Following Breast ImplantAssociated Anaplastic Large Cell Lymphoma. Plast Reconstr Surg 2019; 143: 51S-8S. (PMID: 30817556) [Crossref]

26. Unger CA. Update on Gender-Affirming Treatment for the Transgender Woman. Semin Reprod Med 2017; 35: 442-447. (PMID: 29073683) [Crossref]

27. Moore E, Wisniewski A, Dobs A. Endocrine treatment of transsexual people: a review of treatment regimens, outcomes, and adverse effects. J Clin Endocrinol Metab 2003; 88: 3467-3473. (PMID: 12915619) [Crossref]

28. Chao AH, Garza R, 3rd, Povoski SP. A review of the use of silicone implants in breast surgery. Expert Rev Med Devices 2016; 13: 143-156. (PMID: 26690709) [Crossref]

29. Albornoz CR, Bach PB, Mehrara BJ, Disa JJ, Pusic AL, McCarthy CM, Cordeiro PG, Matros E. A paradigm shift in U.S. Breast reconstruction: increasing implant rates. Plast Reconstr Surg 2013; 131: 15-23. (PMID: 23271515) [Crossref]

30. Gidengil CA, Predmore Z, Mattke S, van Busum K, Kim B. Breast implant-associated anaplastic large cell lymphoma: a systematic review. Plast Reconstr Surg 2015; 135: 713-720. (PMID: 25490539) [Crossref]

31. Fleming D, Stone J, Tansley P. Spontaneous Regression and Resolution of Breast Implant-Associated Anaplastic Large Cell Lymphoma: Implications for Research, Diagnosis and Clinical Management. Aesthetic Plast Surg 2018; 42: 672-678. (PMID: 29445921) [Crossref] 